\title{
REACTION OF SILVER FIR (ABIES $A L B A)$ GROWING OUTSIDE ITS NATURAL RANGE TO EXTREME WEATHER EVENTS AND A LONG-TERM INCREASE IN MARCH TEMPERATURE
}

\author{
MARCIN KOPROWSKI* \\ Nicolaus Copernicus University, Faculty of Biology and Environment Protection, Chair of Ecology and Biogeography, \\ Lwowska 1, 87-100 Torun, Poland
}

\begin{abstract}
Silver fir trees grown outside their natural distributional range were intensively studied in terms of their adaptability to increased late winter temperature and extreme weather events. The main questions of the study are: what is the influence of March temperature increase on tree rings and is the further introduction of silver fir outside its natural range economically justified? A total of 268 cores of silver fir were obtained from 12 sites throughout north Poland, which were located outside its natural range. Next, standard dendrochronological and dendroclimatological methods were applied. The March temperature increase was investigated using the bootstrap running correlation option with a 25year moving window. Response function analysis revealed that the studied trees were more sensitive to winter temperature than to precipitation. Hierarchical cluster analysis identified two distinct geographical regions of fir growth. The positive effect of high March temperature is observed in both regions. Trees from the northwestern Poland region recovered from an extreme cold period in the following year, whereas trees from northeastern Poland were more sensitive, and needed an additional year for recovery. The reason for the relatively fast growth recovery in northwestern Poland is the influence of the mild Atlantic and Baltic climates.
\end{abstract}

Keywords: dendroclimatology, dendroecology, tree rings, silver fir, Abies alba, climate change, north Poland.

\section{INTRODUCTION}

Silver fir (Abies alba Mill.) is found growing naturally in central and southern Europe (Figure 1). Its natural distribution is limited to mountain ranges and massifs, and its northeastern distribution limit runs across Poland, where the occurrence of silver fir is associated mainly with the Carpathian, the Sudetes and the Świętokrzyskie Mountains (Obidowicz et al. 2004). Fir growing outside its natural range in northwestern Poland is characterised by being in good condition and showing natural regeneration. Its occurrence depends mostly on anthropogenic factors, and local climate conditions, especially high annual precipitation totals and low temperatures (Robakowski et al. 2005). As a result of the significant increase of March temperature in Poland observed

\footnotetext{
*E-mail: koper@umk.pl; Telephone: +48 5661147 90; Fax: +48 566114443
}

since 1951 (Kożuchowski and Degirmendžić 2005), there is clearly a need for information about the impact of climate change on the ecology and growth of this species. A warming in the early

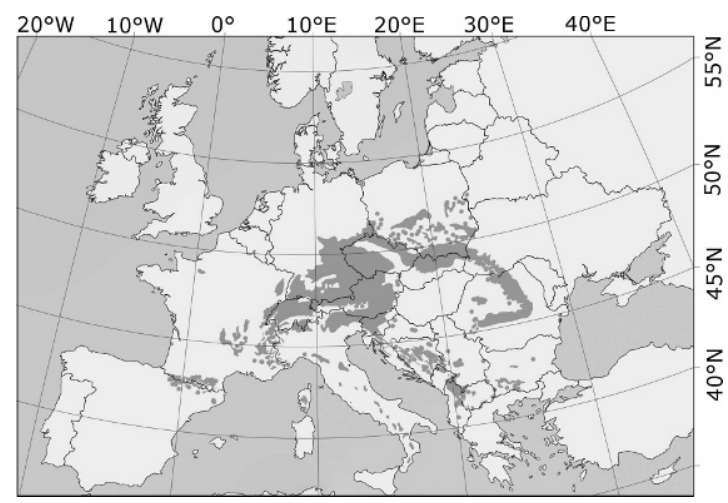

Figure 1. Distribution of Abies alba in Europe. [Courtesy of EUFORGEN, http://www.euforgen.org/distribution_maps. html]. 
spring (February to April) by $1{ }^{\circ} \mathrm{C}$ causes an advanced beginning of growing season of 7 days (Chmielewski and Rötzer 2000). Shortened cold periods during the winter, with warmer temperatures beginning earlier in the spring (Kożuchowski and Degirmendžić 2005) may affect fir growth.

Tree-ring widths in most cases reflect environmental conditions. Some factors such as frost or summer drought, may have an immediate effect on ring width, whereas other factors such as winter drought may have a delayed effect on ring widths, because the growing tissue is dormant during the winter months. The effect of different factors is seen as variation in ring size and structure, which change systematically, or vary slowly throughout the life of the tree (Fritts 1976). Previous dendrochronological studies of trees growing outside their natural distribution and sharing the same area of Poland with silver fir gave promising results in terms of climate-growth relationships and their changes over time (Koprowski 2012, 2013). For Norway spruce (Picea abies), a significant positive influence of high February and March temperatures was identified for most northern sites, along with a negative correlation with temperature of the previous and current growing season (Koprowski 2013). As expected, Norway spruce reacts positively to high rainfall during the growth season in the current and previous year (Koprowski 2013). European larch (Larix decidua) reacts to the temperature of the previous July, August and September. A strong negative correlation was particularly evident for larch from northeastern Poland, affecting both the earlywood and the total ring width (Koprowski 2012).

Tree-ring studies of non-native tree species have been conducted for different regions. Norway spruce growing outside its natural range in southern Italy, was compared with native silver fir. Battipaglia et al. (2009) found that Abies alba was more sensitive to precipitation than nonnative Picea abies. The authors concluded that the reforestation programmes in the Mediterranean region should take into consideration the species that are better adapted to climate change. Such an approach should be taken into account especially when scenarios for global biodiversity suggest that Mediterranean ecosystems will experience a large biodiversity loss (Sala et al. 2000). In some cases the introduction of non-native species creates problems important for local biodiversity. In the Czech Republic Pinus strobus suppresses native vegetation by forming dense monocultural stands and by depositing a thick layer of needle litter (Härtel and Hadincová 1998, after Mácová 2008). The growth of Pinus strobus, native to the eastern part of North America, was compared with that of Pinus sylvestris. No clear link was found between its dendroclimatological response and its invasive behaviour (Mácová 2008). The common European trees like Picea abies and Pinus sylvestris were also introduced to North American forests. Both of these species showed more differential responses to climatic variations in comparison with local Pinus strobus and Pinus resinosa, and this, together with other chronology parameters like signal-to-noiseratio and mean sensitivity, suggest that they are more sensitive to local climate conditions (Kilgore and Telewski 2004).

Taking into account the uncertainties in the climate change projections and the impact of these changes on forests, four main questions are addressed in this paper:

1. How does temperature and precipitation affect the growth of fir outside its natural range?

In Poland, silver fir and European larch growing outside their natural ranges cover almost the same area in northern Poland, while Norway spruce grows outside its natural range in the northwestern part of Poland. Comparison of fir growth with other coniferous species might help to determine which species is better adapted to weather conditions outside its natural distribution. The latter is already sufficiently known for many natural stands (e.g. Rolland 1983; Feliksik 1990; Rolland et al. 1998; Koprowski and Gławenda 2007; Bijak 2010; Bronisz et al. 2010; Carrer et al. 2010; Dittmar et al. 2012; van der MaatenTheunissen et al. 2013)

2. What is the influence of March temperature increase on tree rings?

The early onset of spring (Kożuchowski and Degirmendžić 2005) observed from 1951 
onwards may influence patterns of tree growth in a way similar to that observed for changing June-July temperature in Alaska (D'Arrigo et al. 2008).

3. Are the regional differences related to treegrowth different reactions to climate and extreme weather events?

The spatial distribution of increment patterns allows homogeneous regions to be recognised and generalisations about the climate requirements for non-native species in each area to be made. Fir from Alpine and Mediterranean areas shows different regional responses to most of the climate-related limiting factors along the latitudinal and longitudinal gradients (Carrer et al. 2010). Feliksik (1990) compared fir growth at different sites in Poland and stated that winter temperature was responsible for the high correlation between the sites.

4. Is the further introduction of silver fir outside its natural range economically justified?

In terms of changing climate variables and unpredictable changes in environment, the question of introducing new species outside their natural range is still open. Increased biodiversity within plantations through an increase in the number of species (multispecies plantations) may be an attractive adaptation option, as they are more resilient, or less vulnerable, to climate change (Nabuurs et al. 2007).

\section{MATERIAL AND METHODS}

\section{Material and Study Sites}

A total of 268 cores of silver fir were taken from 12 sites (Figure 2) throughout north Poland at sites outside its natural distributional range. Two core samples were taken from each tree, one from the west and one from the east, using a Pressler borer, at a height of approximately $1.30 \mathrm{~m}$ above the ground. The cores were prepared for measurements using standard dendrochronological procedures (Zielski and Krạpiec 2004).

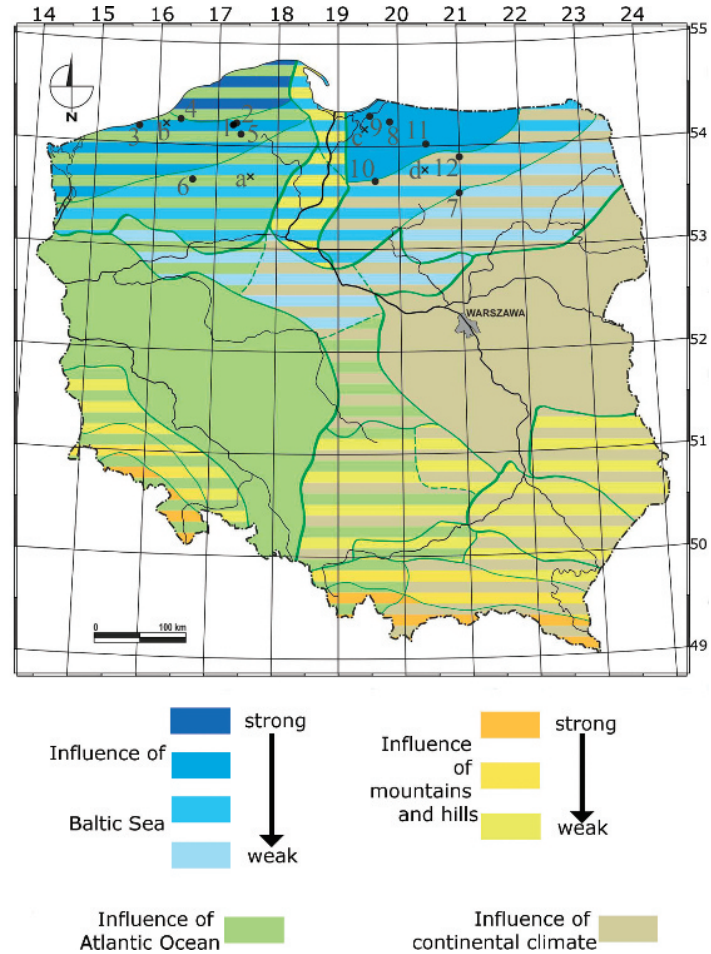

Figure 2. Map of locations of the research sites (•) and meteorological stations $(\times)$ with climatic regions in Poland (according to Okołowicz and Martyn 1984). Numbers of research sites and letters of meteorological stations correspond to those in Table 1 .

Northeastern Poland is connected to the Lowland East-Baltic-Belarus region. From the south to the northeast, the dominance of the Atlantic climate decreases, while the effects of climatic parameters of the continental climate increase. This is expressed especially in decrease in the vegetation growth period and a greater amplitude in annual temperature. The Polish lowland $(60 \%)$ belongs to the Middle-European Lowland, and has generally sub-Atlantic vegetation, with a predominantly oceanic climate. The mean annual precipitation is between $450-700 \mathrm{~mm}$, and the mean annual temperature range is $7-9^{\circ} \mathrm{C}$ (Kondracki 2002).

Southern Poland is mostly uplands and mountains (Kondracki 2002). In northeastern Poland the mean annual temperature is $6.7^{\circ} \mathrm{C}$, while in the southern part it is $8.4^{\circ} \mathrm{C}$. The difference in temperature is clearly visible in January, when the minimum temperature under 
the influence of the continental climate is $-4.2^{\circ} \mathrm{C}$; by contrast, in the southern part it is $-1.4^{\circ} \mathrm{C}$ (Woś 2010). Climate diagrams of the Meteorological Stations in Chojnice, Koszalin, Elbląg and Olsztyn are presented as Online Supplementary Figures S1a-d. Climate data were obtained from the European Climate Assessment \& Dataset (ECA\&D) project (Klein Tank et al. 2002).

\section{Chronology Development}

Basic tree-ring parameters were obtained from the measurement of ring widths to the nearest $0.01 \mathrm{~mm}$ using CooRecorder software combined with the related CDendro program (URL: http://www.cybis.se). Checks on crossmatching were carried out using COFECHA (Holmes 1983). Additionally, each sample was analysed by means of the skeleton plot method after Stokes and Smiley (1968). Both the skeleton plot method and the results from the COFECHA programme were used for evaluating and detecting narrow and wide rings (Grissino-Mayer 2001). The smoothing spline option of the dplR package (Bunn 2008) from R (R Development Core Team 2007) was used to detrend the temporal data series. The "n-year spline" at $2 / 3$ the wavelength of $\mathrm{n}$ years was used (after Cook et al. 1990). The effect of outliers was minimized using Tukey's biweight robust method (Cook et al. 1990). A residual version of the chronology was built by pre-whitening after fitting an autoregressive model to the data using the Akaike Information Criterion (AIC) for variable selection (Bunn 2008). Additionally, the Expressed Population Signal (EPS) was calculated as a measure of the common signal in the chronology (Wigley et al. 1984). Hierarchical cluster analysis (Ward method) was used as implemented in the amap $\mathrm{R}$ package (Author: Lucas) to separate the tree-ring series from each site and to distinguish regions with similar increment patterns (Wilson and Hopfmueller 2001). The idea of hierarchical clustering (Ward method) is to maximize the between-group variance, while minimizing the within-group variance (Ward 1963). Pearson's correlation coefficient was used as a measure of similarity. K-means clustering was then used to group the indices of tree-ring series in selected years. At first, the number of clusters is given a priori. In this case two groups were chosen. Next, a current set of means (residual values of TRW) is minimized by assigning each observation to the closest cluster mean (Hastie et al. 2009, pp. 509-510).

\section{Dendroclimatological Analysis}

In order to investigate climate/growth relationships, the DendroCLIM 2002 software was applied (Biondi and Waikul 2004) using a bootstrap procedure to estimate the error. Climate data from May (previous year) to September (current year) served as independent variables and the regional residual chronologies were used as dependent variables with a common period of 1951-2009. For each region the climate data were taken from the nearest meteorological stations and mean values were counted as the arithmetic mean (Figure 2, Table 1). The March temperature increase was investigated using the bootstrap running correlation option with a 25-year moving window (package bootRes, Author: Zang). Figure 3 shows the linear trend for March temperature increase.

\section{RESULTS}

\section{Tree-Ring Parameter Chronologies}

The hierarchical cluster analysis identified two distinct regions of fir growth (Figure 4). The first region is characterised by a maritime climate. The second region is a mixture of Baltic climate and continental aspects. Among the selected sites, the oldest trees (130-140 years old) were found in the Bytów Forest Inspectorate at site 5, and the chronology for these trees covers the years 18902006 (region 1, Online Supplementary Table S1). Mean tree-ring widths varied from $1.12 \mathrm{~mm}$ (site 7) to $3.10 \mathrm{~mm}$ (site 6). The narrowest earlywood (EW) and latewood (LW) were found in trees from site 7, as was the narrowest overall tree-ring width (TRW). In contrast, the widest EW was noted in site 5 and LW in site 3 (Supplementary Table S2). The portion of the LW in the tree-ring widths (TRW) is comparable and varies from $48.5 \%$ (region 1) to $47.7 \%$ (region 2) (Table 2). The Rbar 
Table 1. Location of the research sites. The sites (numbers) correspond to those in Figures 2 and 4 and meteorological stations (letters) to those in Figure 2. Ff $=$ mesic forest, Fmf $=$ mesic mixed forest.

\begin{tabular}{|c|c|c|c|c|c|c|}
\hline Site number & $\begin{array}{c}\text { Forest } \\
\text { Inspectorate }\end{array}$ & Region & Latitude and & Longitude & Forest site & $\begin{array}{c}\text { Meteorological Station, Elevation, } \\
\text { Latitude and Longitude, Time } \\
\text { span of climate series }\end{array}$ \\
\hline 1 & Osusznica 1 & Region 1 & $54^{\circ} 06^{\prime} 49.5^{\prime \prime} \mathrm{N}$ & $17^{\circ} 22^{\prime} 33.3^{\prime \prime} \mathrm{E}$ & Fmf & a. Chojnice, $172,53^{\circ} 42^{\prime} \mathrm{N}, 17^{\circ} 33^{\prime} \mathrm{E}$ \\
\hline 2 & Osusznica 2 & & $54^{\circ} 06^{\prime} 42.7^{\prime \prime} \mathrm{N}$ & $17^{\circ} 23^{\prime} 09.7^{\prime \prime} \mathrm{E}$ & $\mathrm{Ff}$ & Temperature and precipitation \\
\hline 3 & Goscino & & $54^{\circ} 10^{\prime} 14.2^{\prime \prime} \mathrm{N}$ & $15^{\circ} 41^{\prime} 35.5^{\prime \prime} \mathrm{E}$ & $\mathrm{Ff}$ & $1951-2009$ \\
\hline 4 & Karnieszewice & & $54^{\circ} 15^{\prime} 07.8^{\prime \prime} \mathrm{N}$ & $16^{\circ} 22^{\prime} 28.8^{\prime \prime} \mathrm{E}$ & Fmf & b. Koszalin, $32,54^{\circ} 12^{\prime} \mathrm{N}, 16^{\circ} 08^{\prime} \mathrm{E}$ \\
\hline 5 & Bytów & & $54^{\circ} 13^{\prime} 19.5^{\prime \prime} \mathrm{N}$ & $17^{\circ} 18^{\prime} 05.1^{\prime \prime} \mathrm{E}$ & Fmf & Temperature and precipitation \\
\hline 6 & Szczecinek & & $53^{\circ} 39^{\prime} 46^{\prime \prime} \mathrm{N}$ & $16^{\circ} 36^{\prime} 11^{\prime \prime} \mathrm{E}$ & $\mathrm{Ff}$ & $1951-2009$ \\
\hline 7 & Szczytno & Region 2 & $53^{\circ} 32^{\prime} 11.1^{\prime \prime} \mathrm{N}$ & $20^{\circ} 58^{\prime} 32.6^{\prime \prime} \mathrm{E}$ & $\mathrm{Ff}$ & c. Elbląg, $38,54^{\circ} 10^{\prime} \mathrm{N}, 19^{\circ} 26^{\prime} \mathrm{E}$ \\
\hline 8 & Zaporowo & & $54^{\circ} 14^{\prime} 34.9^{\prime \prime} \mathrm{N}$ & $19^{\circ} 51^{\prime} 02.1^{\prime \prime} \mathrm{E}$ & $\mathrm{Ff}$ & Temperature 1954-2005 \\
\hline 9 & Elbląg & & $54^{\circ} 17^{\prime} 56.5^{\prime \prime} \mathrm{N}$ & $19^{\circ} 31^{\prime} 02.4^{\prime \prime} \mathrm{E}$ & $\mathrm{Ff}$ & Precipitation 1944-2004 \\
\hline 10 & Iława & & $53^{\circ} 39^{\prime} 46.8^{\prime \prime} \mathrm{N}$ & $19^{\circ} 36^{\prime} 03.5^{\prime \prime} \mathrm{E}$ & $\mathrm{Ff}$ & d. Olsztyn, $133,53^{\circ} 46^{\prime} \mathrm{N}, 20^{\circ} 25^{\prime} \mathrm{E}$ \\
\hline 11 & Wichrowo & & $54^{\circ} 01^{\prime} 30.2^{\prime \prime} \mathrm{N}$ & $20^{\circ} 26^{\prime} 46.8^{\prime \prime} \mathrm{E}$ & Fmf & Temperature and precipitation \\
\hline 12 & Wipsowo & & $54^{\circ} 53^{\prime} 28.4^{\prime \prime} \mathrm{N}$ & $20^{\circ} 59^{\prime} 40.4^{\prime \prime} \mathrm{E}$ & $\mathrm{Ff}$ & $1951-2009$ \\
\hline
\end{tabular}

and EPS of TRW for sites varied from 0.295 to 0.571 , and from 0.670 to 0.908 , respectively (Supplementary Table S1). For 8 sites the EPS values for TRW were above the frequently applied threshold of 0.85 (Supplementary Table S1), indicating robust mean value functions (Wigley et al. 1984). Regional EPS is higher than 0.85 (Table 2) and seems to be more promising, suggesting that the sample size is adequate
(McCarroll and Loader 2004). Furthermore, the regional values of EPS for latewood and earlywood mean that the common signal in LW and EW is reliable for dendroclimatic study (Table 2). Taking each site separately, an EPS above 0.85 was found for both EW and LW at five sites (Supplementary Table S2). The mean sensitivity and first-order autocorrelation for TRW range from 0.258 to 0.358 and from 0.651 to 0.827 ,

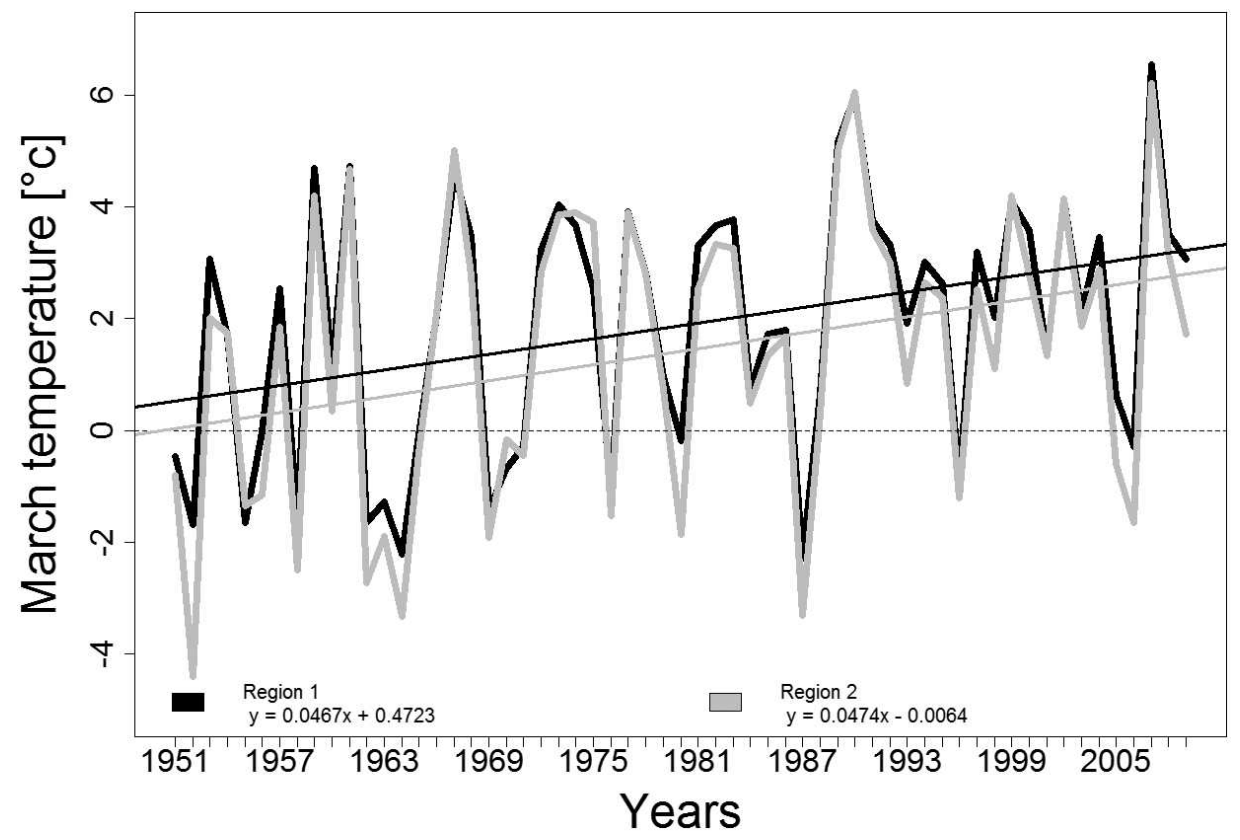

Figure 3. The increase of March temperature in both regions, which follow a positive linear trend. 


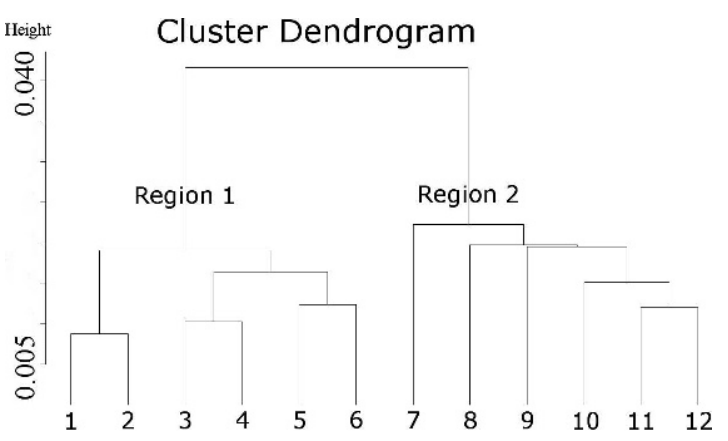

Figure 4. Dendrogram of the results of cluster analysis. Numbers of research sites correspond to those in Table 1.

respectively, giving information about year-toyear variation in raw data chronologies for each site.

\section{Climate Effect}

A negative effect of temperature of the previous year was found in region 1 for EW and relates to July, September and October temperature. A positive correlation was observed for TRW and LW from January to March in both regions. High temperature in May, on the other hand, had a general negative impact on EW in both regions (Figure 5a). The influence of temperature on treering widths, latewood and earlywood is comparable. The cross-correlation between the responses of TRW, EW, LW and temperature varied for both regions from $0.69(\mathrm{p}<0.01)$ to 0.98 ( $\mathrm{p}<$ 0.01 ). The most homogeneous reaction is between TRW, EW, LW and temperature from January to March. In region 1, correlation is between 0.96 $(\mathrm{p}<0.05)$ and $0.99(\mathrm{p}<0.05)$ and in region 2 for each parameter is $0.99(\mathrm{p}<0.05)$. In total, $25 \%$ of the temperature correlations for all months were significant at $\mathrm{p}<0.05$. Precipitation had mixed effects on ring width. Low precipitation in the previous September and high precipitation in February, May and July increased tree growth (10\% of all significant correlations for precipitation) (Figure 5b). In contrast to temperature, the correlation between growth-precipitation relationships is lower and varies from $0.49(\mathrm{p}<0.05)$ to 0.97 ( $\mathrm{p}<0.001)$. The bootstrap running correlation with a 25 -year moving window revealed the positive effect of high March temperature in both regions, especially for TRW and LW (Figure 6). The visual assessment and analysis of extreme ring widths using COFECHA revealed the occurrence of extremely narrow rings in 1929, 1940, 1956 and 2006. In these years, the residual values of the master dating series were below -2.0 in at least one region. Trees from region 1 recover in the following year, especially in 1941 and 1957. In contrast to region 1, trees from region 2 recover later. K-means clustering revealed that in region 2 only trees from site 9 recover in 1941(Figure 7a). The growth of trees from region 2 in the years 1956-1958 is not so homogenous. Trees from sites 9, 10 and 11 need more time to recover and in 1958 still reveal narrow rings (Figure $7 \mathrm{~b}$ ).

\section{DISCUSSION}

\section{Influence of Temperature and Precipitation and the Effect of Extreme Weather Conditions}

The effect of temperature and precipitation on fir growth should be considered in two aspects:

Table 2. Descriptive statistics for arithmetic means in each region. TRW = tree-ring widths; $\mathrm{EW}=$ earlywood; LW = latewood; Rbar.eff $=$ the effective signal calculated as rbar.bt/(rbar.wt + (1-rbar.wt)/c.eff), where: rbar.wt is the mean of the correlations between series from the same tree over all trees, rbar.bt is the mean inter-series correlation between all series from different trees; c.eff $=$ the effective number of cores; EPS $=$ the expressed population signal.

\begin{tabular}{|c|c|c|c|c|c|c|}
\hline & & Series & Period & $\begin{array}{c}\text { Mean } \\
\text { measurement }(\mathrm{mm})\end{array}$ & Rbar effective & EPS \\
\hline & TRW & & & 2.68 & 0.316 & 0.956 \\
\hline \multirow[t]{3}{*}{ Region 1} & EW & 133 & 1898-2009 & 1.30 & 0.265 & 0.944 \\
\hline & LW & & & 1.38 & 0.251 & 0.940 \\
\hline & TRW & & & 2.43 & 0.381 & 0.964 \\
\hline \multirow[t]{2}{*}{ Region 2} & EW & 135 & 1898-2009 & 1.16 & 0.322 & 0.954 \\
\hline & LW & & & 1.27 & 0.320 & 0.954 \\
\hline
\end{tabular}


firstly in comparison within the same species from the natural distribution, and secondly, between European larch growing in the same area outside its natural range and Norway spruce introduced to northwestern Poland as a result of forest management. However, the species differ in terms of their ecological requirements, i.e. spruce relies more on water reserves than fir and larch (Larcher 2003). The studied trees grow in lowland areas, in contrast to the trees from natural distributions that are mostly from high altitude; Boratyński (1983) considered fir to be a species of mountainous areas. Previous findings emphasized that fir from outside its natural range in the lowlands is sensitive to winter temperature (Koprowski and Gławenda 2007; Bijak 2010). Winter temperature is also the most important limiting factor influencing distribution in both southern Poland and the western Ukraine (Feliksik 1990; SzychowskaKrapiec 2010; Iszkuło et al. 2011). However, the opposite relationship between March temperature and fir growth was observed in the Świętokrzyskie Mountains. This may be caused by sudden temperature decreases during the relatively warm period (Bronisz et al. 2010). The present study identified that the effect of temperature is comparable between regional chronologies for TRW, EW and LW and the correlation coefficients being $0.88(\mathrm{p}<0.001), 0.92(\mathrm{p}<0.001)$ and $0.93(\mathrm{p}<$ 0.001 ), respectively. Except EW (region 1), significant bootstrap correlation values were observed for temperature from January to March (Figure 5a). Similar relationships are found for fir in southwestern Germany above $900 \mathrm{~m}$ a.s.l. (van der Maaten-Theunissen et al. 2013). From the ecophysiological point of view, the importance of temperature in late winter is related to photosynthetic activity, which in the case of fir, may be activated by relatively high temperature (Guehl 1985). It could stimulate carbohydrate storage and, as a result, the growth in the current year (Lebourgeois 2007).

In the current research, $13 \%$ of all significant correlations for TRW with precipitation for separate sites were significant at $\mathrm{p}<0.05$, whereas $20 \%$ of temperature correlations were significant at $\mathrm{p}<0.05$. The mean significant negative correlation coefficient for temperature is -0.30 and the significant positive value is 0.35 , whereas for precipitation the correlation coefficients are -0.21 and 0.30 , respectively. The influence of temperature on EW and LW is higher than the effect of precipitation, i.e. for EW $8 \%$ of all correlations are significant for precipitation and $28 \%$ for temperature, whereas for LW they are $14 \%$ and $17 \%$, respectively. In the Eastern Carpathian Mountains, temperature is less significantly correlated than precipitation (Bouriaud and Popa 2009). The limiting factors, on fir growth from low elevation in French Alpine sites, are winter frost and summer aridity (Desplanque et al. 1999), whereas at upper levels the weather conditions in the summer season are more important (Rolland 1983; Desplanque et al. 1999). Temperature in February was positively correlated with TRW at $92 \%$ of all sites and precipitation at $33 \%$. From a regional perspective, there is a clear correlation between EW and precipitation from both regions (Figure 5b). The positive effects of high temperature and precipitation in February are associated with relatively warm air (low-pressure areas) (van der Maaten-Theunissen et al. 2013).

As expected, trees reacted positively to high rainfall in the current growing season, especially in May. A negative correlation with temperature and a positive correlation with precipitation during the growing season were observed in most of the studies (e.g. Bouriaud and Popa 2009; Carrer et al. 2010; van der Maaten-Theunissen et al. 2013).

Fir is highly sensitive to extremely low temperature (Jaworski and Zarzycki 1983). Response function analysis revealed that the studied trees were more sensitive to winter temperature than to precipitation. According to the weather records of the Institute of Meteorology and Water Management in Warsaw, the lowest temperature in Poland, below $-40^{\circ} \mathrm{C}$ was noted in 1929 and 1940 and $-35^{\circ} \mathrm{C}$ or below in 1956, 1963 and 1964, 2006 and 2012. As a result, narrow rings in 1929 and 2006 appeared in trees from region 2. In both regions, reductions in ring widths were observed in 1940 and 1956; however, differences can be seen in their recovery times. Trees from five sites from region 2 show narrow rings in 1941, whereas trees from region 1 have wider rings in 1941 (Figure 7a). In 1957 narrow rings are observed in trees 


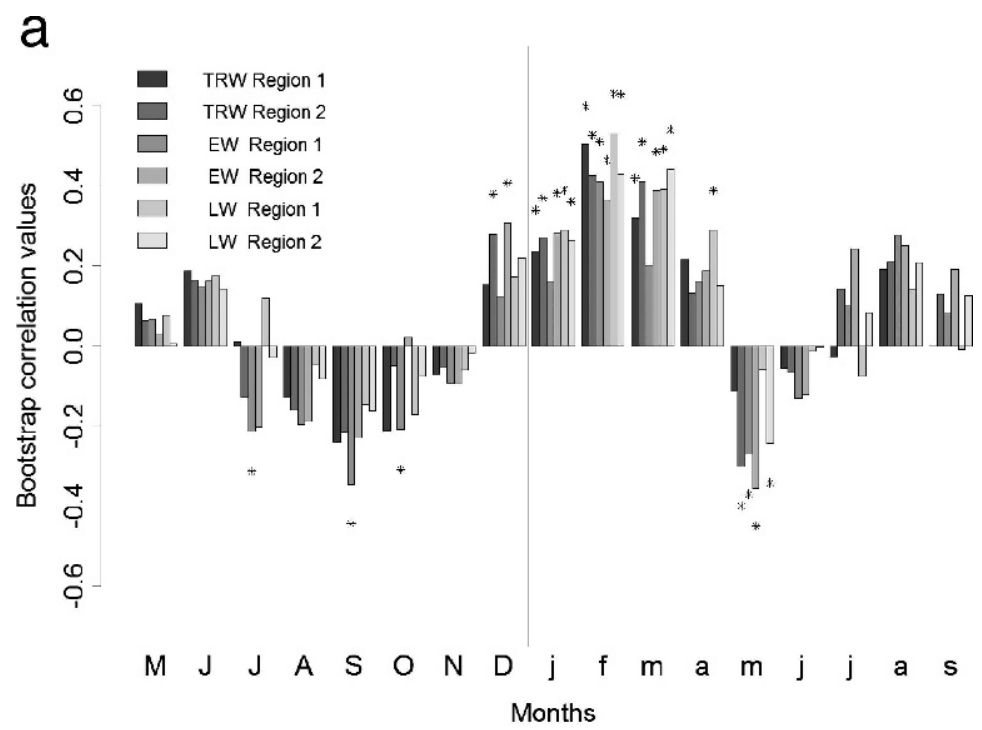

b

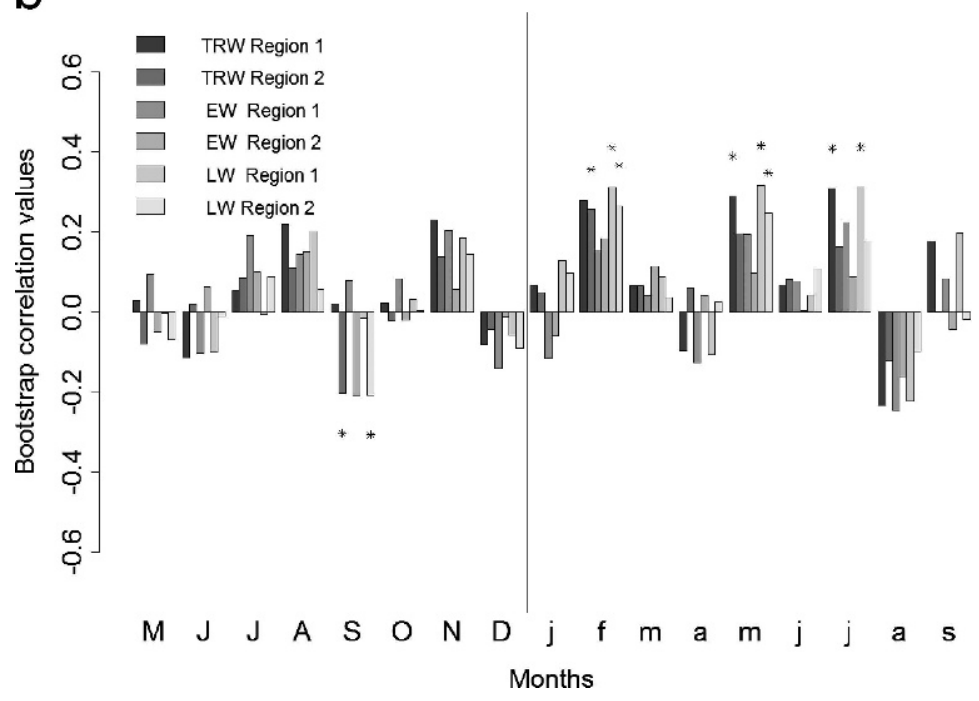

Figure 5. Relationships between growth and temperature (a) and between growth and precipitation (b) in each region. TRW $=$ treering width; $\mathrm{EW}=$ earlywood; $\mathrm{LW}=$ latewood. Asterisk $(*)$ indicates significance at $\mathrm{p}<0.05$. Left side of each panel shows previous year, right site shows current year.

from sites 9, 10 and 11 (Figure 7b). A negative effect of cold winters in 1929, 1940 or 1956 was observed in southern Germany, but none of these instances initiated a long-lasting growth depression in these trees that were affected by $\mathrm{SO}_{2}$ (Elling et al. 2009). In the present study it was shown that the extremely low temperature in region 2 may lead to a growth reduction lasting a year longer $(1941,1957)$ and after that, if narrow rings appear, they were not extreme. Region 2 is situated in northeastern Poland, meaning that the trees are growing under the influence of the continental climate, with a decrease in the growth period, and a greater yearly temperature amplitude (Kondracki 2002). Sites 8 and 9, even though they are located in region 2 , are also under the influence of the mild Baltic climate. From a regional point of view, the trees from region 1 

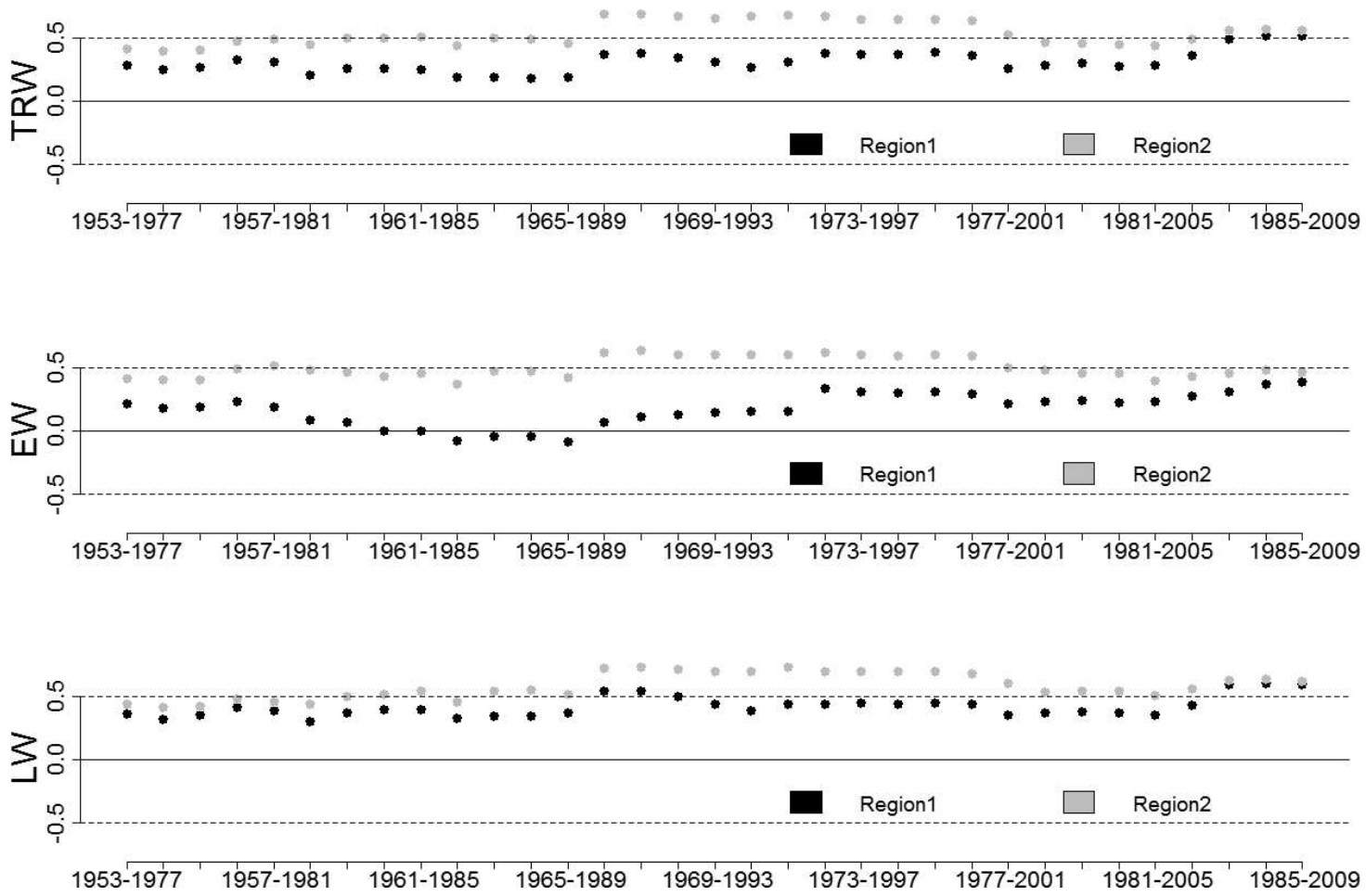

Figure 6. Change in influence of March temperature on tree-ring widths in sequential 25-year time intervals. TRW = tree-ring width; EW = earlywood; LW = latewood.

recover from the extreme cold period in the next year, whereas trees from region 2 are more sensitive, and need an extra year for recovery. Northeastern Poland has four frost-free months (Olsztyn Meteorological Station), whereas region 1 has five frost-free months (Supplementary Figures S1a-d). Elblag, which is located within region 2 , is more under the influence of the Baltic Sea. In region 2 , the reason for the quicker recovery of trees from site 9 in 1941 and sites 7 and 8 in 1957 is the influence of the mild Atlantic and Baltic climates.

Silver fir is much more sensitive to severe frost than to drought. The analysis of extreme narrow rings discussed above confirms this assumption. In Germany the fir dieback in and after drought periods, e.g. 1976, was caused by an attack of parasitic fungi (Seitschek 1981), so in this case the reduction after the drought is a secondary effect (Elling et al. 2009).

In this research, fir dieback was not observed, the condition of the trees was good, and in most of the sites seedlings were very common. According to Jaworski and Zarzycki (1983) mean January temperature below $-4.5^{\circ} \mathrm{C}$ is a limiting factor. However, in region 2 lower temperatures, for instance in $1963\left(-12.2^{\circ} \mathrm{C}\right.$ in Olsztyn Meteorological Station), led to growth reduction, not to species dieback. This may be explained by wider ecological requirements than are observed in its natural range.

\section{Effect of Increasing Temperature}

The reaction to winter temperature seems to be a major factor that controls the spatial distribution of tree growth in lowland Poland, as was also observed in southern sites (Feliksik 1990). In the case of fir, winter temperature is the most crucial factor. There has been a significant increase of March temperature in Poland (Kożuchowski and Degirmendžić 2005) in recent years, and given the positive significant bootstrap correlation between March temperature and TRW, EW and LW, the changing climate might 

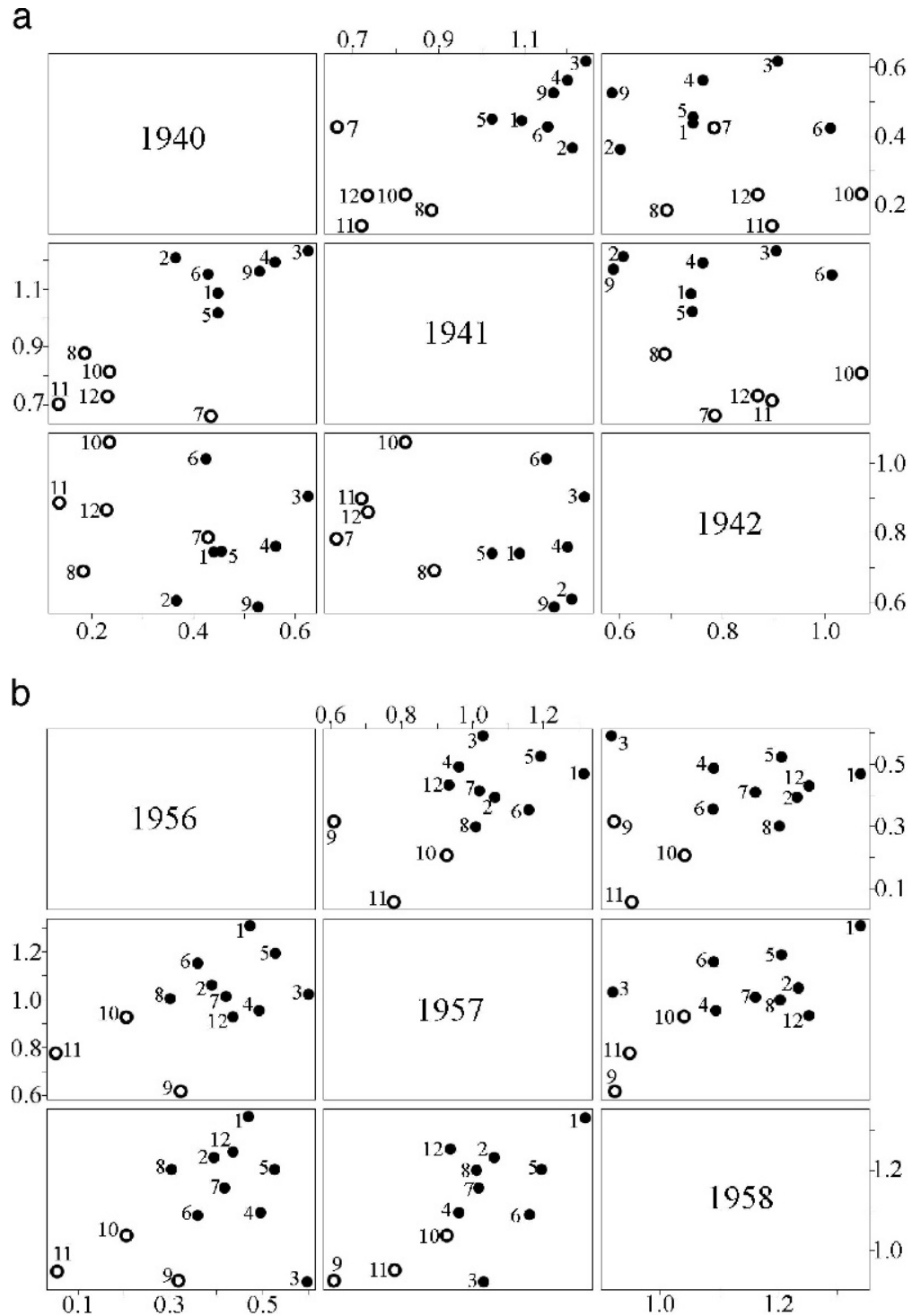

Figure 7. Diagram of results of k-means analysis for years 1940-1942 (a) and 1956-1958 (b). Circles and dots represent the sites and numbers correspond to those in Table 1. The sites were grouped on the basis of TRW indexed values. On each graph two groups of sites were identified, the first one by circles $(\bigcirc)$ and the second one by dots $(\bullet)$. In Figure 7a, the comparison between index values of TRW in 1940 and 1941 shows the narrow rings for trees from sites 7, 8, 10, 11, 12 in 1941 and in 1940, except at site 7. In Figure 7b, TRW indices for 1956 and 1957 from sites 9, 10 and 11 were grouped into one cluster that represents tree sites with narrow rings.

cause different seasonal reactions of tree growth to these temperature changes. The "divergence problem" has been observed in northern Alaskan forests where it is associated with increasing June-July mean temperatures (D'Arrigo et al. 2008). In fact, this is common for Northern Hemisphere trees, and different factors might be involved, such as increasing atmospheric $\mathrm{CO}_{2}$, higher levels of pollutant transport (i.e. nitrates or phosphates), other changes in soil chemistry, or increased UV-B levels (Briffa et al. 1998). The correlation observed here, using a 25 -year moving window, revealed a positive, constant impact of late winter temperatures during the whole period 
(Figure 6), especially in the case of TRW and LW. It is worthwhile to emphasize that for Larix decidua and Picea abies the same values vary about zero (Koprowski 2012, 2013). This is a result of fir sensitivity to low winter temperature.

The exclusion of 15 cold years from the meteorological data (mean temperature below $-3^{\circ} \mathrm{C}$ from December to February at least in one station) and 15 rings from following years in region 1, and 19 rings from region 2, confirmed this assumption. In this case, the significant values of correlation between tree-ring width and winter temperatures on tree-ring widths were not observed in either region 1 or in region 2. The increase of March temperature may stimulate fir growth and natural regeneration of this species outside its natural range, and in areas adjacent to its distribution limits in lowland Poland.

\section{CONCLUSIONS}

The research presented here identifies that the observed recent increased March temperature has a positive effect on tree-ring widths. The presence of silver fir seedlings together with the observed lack of a negative response of tree growth to the increase in March temperature suggests that wider introduction of fir outside its natural distributional range may be beneficial. It is worth noting, however, that the further introduction of this species to northeastern Poland may not be as beneficial. Here, fir, which is more sensitive to sudden frost, may suffer because of the more continental climate. On the other hand, because of the uncertainties in the climate change projections and an incomplete understanding of tree responses to the changing climatic factors (Lindner et al. 2008), it is impossible to predict the final effect of changes on silver fir growth. One possible solution to ameliorate the impact of climate change on forests is to extend the surface area of the forest and to increase the biodiversity within plantations by increasing the number of species (multi-species plantations) (Nabuurs et al. 2007). The introduction of Abies alba to northwestern Poland, and to a lesser extent to northeastern Poland, may in the long-term be crucial for both forest management and the biodiversity of these areas.

\section{ACKNOWLEDGMENTS}

This work was supported by the National Science Centre in the years 2011-2013, habilitation grant number N N309 7091410. I thank Martin Bridge for language correction and Werner Ulrich for discussions on the manuscript. I also thank Jerzy Miałdun for drawing maps (Figure 2) and EUFORGEN for permission to use Abies alba distribution map (Figure 1). Special thanks I owe to the staff of The State Forests for their hospitality and help. This paper is a part of the habilitation thesis. This paper is related to COST Action FP1106.

\section{REFERENCES CITED}

Battipaglia, G., M. Saurer, P. Cherubini, R. T. W. Siegwolf, and M. F. Cotrufo, 2009. Tree rings indicate different drought resistance of a native (Abies alba Mill) and a nonnative (Picea abies (L.) Karst) species co-occurring at a dry site in Southern Italy. Forest Ecology and Management 257: 820-828.

Bijak, S., 2010. Tree-ring chronology of silver fir and its dependence on climate of the Kaszubskie Lakeland (Northern Poland). Geochronometria 35:91-94.

Biondi, F., and K. Waikul, 2004. DENDROCLIM 2002: A C++ program for statistical calibration of climate signals in treering chronologies. Computer and Geosciences 30:303-311.

Boratyński, A., 1983. Systematyka i geograficzne rozmieszczenie. In Jodla Pospolita Abies alba Mill, edited by S. Białobok, pp. 41-85. Nasze Drzewa Leśne. Monografie Popularnonaukowe.

Bouriaud, O., and I. Popa, 2008. Comparative dendroclimatic study of Scots pine, Norway spruce, and silver fir in the Vrancea Range, Eastern Carpathian Mountains. TreesStructure and Function 23:95-106.

Briffa, K., F. H. Schweingruber, P. Jones, T. Osborn, I. Harris, S. Shiyatov, A. Vaganov, and H. Grudd, 1998. Trees tell of past climates: But are they speaking less clearly today? Philosophical Transactions B 353:65-73.

Bronisz, A., S. Bijak, and K. Bronisz, 2010. Dendroklimatologiczna charakterystyka jodły pospolitej (Abies alba Mill.) na terenie Gór Świętokrzyskich. Sylwan 154:463-470.

Bunn, A. G., 2008. A dendrochronology program library in $\mathrm{R}$ (dplR). Dendrochronologia 26:115-124.

Carrer, M., P. Nola, R. Motta, and C. Urbinati, 2010. Contrasting tree-ring growth to climate responses of Abies alba toward the southern limit of its distribution area. Oikos 119:1515-1525.

Chmielewski, F. M., and Th. Rötzer, 2000. Phenological trends in Europe in relation to climatic changes. Agrarmeteorologische Schriften 7:1-15.

Cook, E. R., K. Briffa, S. Shiyatov, A. Mazepa, and P. D. Jones, 1990. Data analysis. In Methods of Dendrochronology: 
Applications in the Environmental Sciences, edited by E. R. Cook, and L. A. Kairiukstis, pp. 97-162. Kluwer Academic Publishers, Dodrecht.

D’Arrigo, R., R. Wilson, B. Liepert, and P. Cherubini, 2008. On the "Divergence Problem" in Northern Forests: A review of the tree-ring evidence and possible causes. Global and Planetary Change 60:289-305.

Desplanque, C., C. Rolland, and F. H. Schweingruber, 1999. Influence of species and abiotic factors on extreme tree ring modulation: Picea abies and Abies alba in Tarentaise and Maurienne (French Alps). Trees-Structure and Function 13: 218-227.

Dittmar, C., T. Eißing, and A. Rothe, 2012. Elevation-specific tree-ring chronologies of Norway spruce and silver fir in Southern Germany. Dendrochronologia 30:73-83.

Elling, W., Ch. Dittmar, K. Pfaffelmoser, and T. Rötzer, 2009. Dendroecological assessment of the complex causes of decline and recovery of the growth of silver fir (Abies alba Mill.) in Southern Germany. Forest Ecology and Management 257:1175-1187.

Feliksik, E., 1990. Badania Dendroklimatologiczne Dotyczace Jodly (Abies alba Mill.) Występujacej na Obszarze Polski. Zeszyty Naukowe Akademii Rolniczej im. H.Kołłąaja w Krakowie. Rozprawa habilitacyjna nr 151, 105 pp.

Fritts, H., 1976. Tree Rings and Climate. Academic Press, London, New York, San Francisco; 567 pp.

Grissino-Mayer, H., 2001. Evaluating crossdating accuracy: A manual and tutorial for the computer program COFECHA. Tree-Ring Research 57:205-221.

Guehl, J., B. Clerc, and J. Desjeunes, 1982. Étude comparée des potentialités hivernales d'assimilation carbonée de trois conifères de la zone tempérée (Pseudotsuga menziesii Mirb., Abies alba Mill. et Picea excelsa Link). Annals of Forest Science 42:23-38.

Hastie, T., R. Tibshirani, and J. Friedman, 2008. The Elements of Statistical Learning. Data Mining, Inference, and Prediction. Springer Series in Statistics, 739 pp.

Holmes, R. L., 1983. Computer-assisted quality control in treering dating and measurement. Tree-Ring Bulletin 43:69-78.

Iszkuło, G., A. Jasińska, and K. Sobierajska, 2011. Dendroecological differences between Taxus baccata males and females in comparison with monoecious Abies alba. Dendrobiology 65:55-61.

Jaworski, A., and K. Zarzycki, 1983. Ekologia. In Jodła Pospolita Abies alba Mill, edited by S. Białobok, pp. 315-430. Nasze Drzewa Leśne. Monografie Popularnonaukowe.

Kilgore, J. S., and F. W. Telewski, 2004. Climate-growth relationships for native and nonnative Pinaceae in Northern Michigan's Pine Barrens. Tree-Ring Research 60:3-13.

Klein Tank, A. M. G., J. B. Wijngaard, G. P. Können, R. Böhm, G. Demarée, A. Gocheva, M. Mileta, S. Pashiardis, L. Hejkrlik, C. Kern-Hansen, R. Heino, P. Bessemoulin, G. Müller-Westermeier, M. Tzanakou, S. Szalai, T. Pálsdóttir, D. Fitzgerald, S. Rubin, M. Capaldo, M. Maugeri, A. Leitass, A. Bukantis, R. Aberfeld, A. F. V. van Engelen, E. Forland, M. Mietus, F. Coelho, C. Mares, V. Razuvaev, E. Nieplova, T. Cegnar, J. Antonio López, B. Dahlström, A. Moberg, W. Kirchhofer, A. Ceylan, O. Pachaliuk, L. V.
Alexander, and P. Petrovic, 2002. Daily dataset of 20thcentury surface air temperature and precipitation series for the European Climate Assessment. International Journal of Climatology 22:1441-1453.

Kondracki, J., 2002. Geografia regionalna Polski. Warszawa: Wydawnictwo Naukowe PWN, 440 pp.

Koprowski, M., 2012. Long-term increase of March temperature has no negative impact on tree rings of European larch (Larix decidua) in lowland Poland. Trees-Structure and Function 26:1895-1903.

Koprowski, M., 2013. Spatial distribution of introduced Norway spruce growth in lowland Poland: The influence of changing climate and extreme weather events. Quaternary International 283:139-146.

Koprowski, M., and M. Gławenda, 2007. Dendrochronologiczna analiza przyrostów rocznych jodły pospolitej (Abies alba Mill.) na Pojezierzu Olsztyńskim (Nadleśnictwo Wichrowo). Sylwan 151:35-40.

Kożuchowski, K., and J. Degirmendžić, 2005. Contemporary changes of climate in Poland: trends and variation in thermal and solar conditions related to plant vegetation. Polish Journal of Ecology 53:283-297.

Larcher, W., 2003. Physiological Plant Ecology. Springer, Berlin; 513 pp.

Lebourgeios, F., 2007. Climatic signal in annual growth variation of silver fir (Abies alba Mill.) and spruce (Picea abies Karst.) from the French Permanent Plot Network (RENECOFOR). Annals of Forest Science 64:333-343.

Lindner, M., M. Lindner, J. Garcia-Gonzalo, M. Kolström, T. Green, R. Reguera, M. Maroschek, R. Seidl, M. J. Lexer, S. Netherer, A. Schopf, A. Kremer, S. Delzon, A. Barbati, M. Marchetti, and P. Corona, 2008. Impacts of Climate Change on European Forests and Options for Adaptation. AGRI-2007G4-06, Report to the European Commission DirectorateGeneral for Agriculture and Rural Development, 173 pp.

Mácová, M., 2008. Dendroclimatological comparison of native Pinus sylvestris and invasive Pinus strobus in different habitats in the Czech Republic. Preslia 80:277-289.

McCarroll, D., and N. J. Loader, 2004. Stable isotopes in tree rings. Quaternary Science Reviews 23:771-801.

Nabuurs, G. J., O. Masera, K. Andrasko, P. Benitez-Ponce, R. Boer, M. Dutschke, E. Elsiddig, J. Ford-Robertson, P. Frumhoff, T. Karjalainen, O. Krankina, W. A. Kurz, M. Matsumoto, W. Oyhantcabal, N. H. Ravindranath, M. J. Sanz Sanchez, and X. Zhang, 2007. Forestry. In Climate Change 2007: Mitigation of Climate Change, Contribution of Working Group III to the Fourth Assessment Report of the Intergovernmental Panel on Climate Change, edited by B. Metz, O. R. Davidson, P. R. Bosch, R. Dave, and L. A. Meyer, pp. 541-584. Cambridge University Press, Cambridge, United Kingdom and New York,, NY, U.S.A.

Obidowicz, A., K. Szczepanek, E. Madeyska, and D. Nalepka, 2004. Abies alba Mill.-Fir. In Late Glacial and Holocene History of Vegetation in Poland Based on Isopollen Maps, edited by M. Ralska-Jasiewiczowa, pp. 31-38. Institute of Botany, Polish Academy of Sciences, Kraków.

Okołowicz, W., and D. Martyn, 1984. Regiony klimatyczne. In Atlas Geograficzny Polski, 10 pp. PPWK, Warszawa. 
R Development Core Team, 2007. R: A language and environment for statistical computing. $R$ Foundation for Statistical Computing, Vienna, Austria. ISBN 3-900051-07-0, URL http://www.R-project.org.

Robakowski, P., B. Standio, and B. Bułaj, 2005. Występowanie i przydatność hodowlana jodły pospolitej (Abies alba Mill.) poza granicami jej naturalnego zasięgu. Sylwan 149:18-30.

Rolland, C., 1983. Tree-ring and climate relationships for Abies alba in the internal Alps. Tree-Ring Bulletin 53:1:11.

Rolland, C., V. Petitcolas, and R. Michalet, 1998. Changes in radial tree growth for Picea abies, Larix decidua, Pinus cembra and Pinus uncinata near the alpine timberline since 1750. Trees- Structure and Function 13:40-53.

Sala, O. E., F. S. Chapin, III, J. J. Armesto, E. Berlow, J. Bloomfield, R. Dirzo, E. Huber-Sanwald, L. F. Huenneke, R. B. Jackson, A. Kinzig, R. Leemans, D. M. Lodge, H. A. Mooney, M. Oesterheld, N. L. Poff, M. T. Sykes, B. H. Walker, M. Walker, and D. H. Wall, 2000. Global biodiversity scenarios for the Year 2100. Science 5459:1770-1774.

Seitschek, O., 1981. Verbreitung und Bedeutung der Tannenerkrankung in Bayern. Forstwissenschaftliche Centralblatt 100:138-148.

Stokes, M. A., and Smiley, T. L., 1968. An Introduction to Tree-Ring Dating. University of Arizona Press, Tucson, AZ; $73 \mathrm{pp}$.

Szychowska-Krapiec, E., 2010. Long-Term Chronologies of Pine (Pinus sylvestris L.) and Fir (Abies alba Mill.) from the
Matopolska Region and Their Paleoclimatic Interpretation.. Folia Quaternaria 79, $124 \mathrm{pp}$.

van der Maaten-Theunissen, M., H.-P. Kahle, and E. van der Maaten, 2013. Drought sensitivity of Norway spruce is higher than that of silver fir along an altitudinal gradient in southwestern Germany. Annals of Forest Science 70:185-193.

Ward, J., 1963. Hierarchical grouping to optimize an objective function. Journal of the American Statistical Association 58: 236-244.

Wigley, T., K. R. Briffa, and P. D. Jones, 1984. On the average value of correlated time series, with applications in dendroclimatology and hydrometeorology. Journal of Applied Meteorology and Climatology 23:201-213.

Wilson, R. J. S., and M. Hopfmueller, 2001. Dendrochronological investigations of Norway spruce along an elevational transect in the Bavarian Forest, Germany. Dendrochronologia 19:67-79.

Woś, A., 2010. Klimat Polski w Drugiej Polowie XX Wieku. Poznań: Wydawnictwo Naukowe UAM, 489 pp.

Zielski, A., and M. Krąpiec, 2004. Dendrochronologia. Warszawa: Wydawnictwo Naukowe PWN, 328 pp.

Received 29 October 2012; accepted 20 May 2013

Supplementary Material is available at $h t t p: / / w w w$. treeringsociety.org/TRBTRR/TRBTRR.htm 